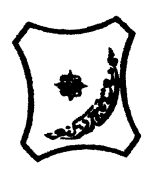

Bayero Journal of Pure and Applied Sciences, 13(1); 64 - 67

Received: April, 2020

Accepted: May, 2020

ISSN $2006-6996$

\title{
THE HEALTH RISK ASSESSMENT OF HEAVY METAL CONCENTRATION IN DRINKING WATER SAMPLES FROM SELECTED LOCATIONS OF KAURU LOCAL GOVERNMENT AREA KADUNA STATE -NIGERIA
}

\author{
Dogara, $K^{1}$, Abdul-Azeez, U.M ${ }^{2}$. and A.M Sani ${ }^{3}$ \\ ${ }^{182}$ Department of Applied Chemistry, College of Science and Technology \\ Kaduna Polytechnic. \\ ${ }^{3}$ Department of Chemistry Kaduna State University, Kaduna. \\ *Corresponding authors; E-Mail:kantomadogara@gmail.com \\ Phone: +2348031592099,+2348028855396
}

\begin{abstract}
Water is one of the vital resources for all kind of life. As a result of this a lot of studies has been carried out to ascertain the quality of drinking water. One of such ways is the determination of heavy metals present due to their impact on human health. This study is aimed at assessing the concentration of some trace metals/element in river water, well water and borehole water in different locations of Kauru local government areas Kaduna state. Atomic Absorption Spectrophotometer (AAS) was used to determine the heavy metal concentration in water. Prior to analysis the water samples were pre-concentrated and the residue dissolved in $0.5 \mathrm{M}$ Nitric acid. Different water samples were analysed for $\mathrm{Fe}$, with concentration level of 230.3 and $47.7 \mu \mathrm{g} / \mathrm{L}$, Co(between 0.00 and $4.76 \mu \mathrm{g} / \mathrm{L}$ ), Cr(between 0.00 and $36.00 \mu \mathrm{g} / \mathrm{L}), \quad C d$ was $0.00 \mu \mathrm{g} / \mathrm{L}$ in all the water samples, $\mathrm{Ni}($ between 0.00 and $4.90 \mu \mathrm{g} / \mathrm{L}$ ). The concentration of all the metals were considerable found to be below the limit permitted by WHO in $\mu g / L$ in drinking water guidelines(WHO

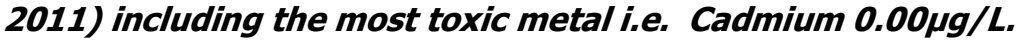

Keywords: Atomic Absorption spectrophotometer, heavy metals, water, Kauru local government area.

\section{INTRODUCTION}

Water is one of the most essential elements to life on earth. In its purest form, it's odorless, colorless and tasteless but due to human and animal activities, it is usually contaminated with solid and human waste, effluents from chemical industries and dissolved gases. Jimoh and Umar (2015). Water contaminated by sewage is estimated to kill about two million children every year (Sa'id, 2008). The acid rain is another major water contaminant. The availability of good quality water is an indispensable feature for preventing diseases and improving quality of life Adefemi and Awokunmi (2007).

In addition, water contains some amount of heavy metals are sometimes called "trace element" they are the metallic elements of the periodic table, they include; Iron $\mathrm{Fe}$, Magnesium $\mathrm{Mg}$, Manganese Mn, Cadmium Cd, Zinc Zn, Copper $\mathrm{Cu}$, Chromium Cr, Nickel Ni, Cobalt Co, Vanadium V, Arsenic As, Molybdenum Mo, Selenium Se, Lead $\mathrm{pb}$, and so many others (Jimoh and Umar,2015). Many of these minerals are required as micronutrients (small amount). Concentrations of trace elements in water vary because of physiological, environmental and other factors (Sa'id, 2008). Some trace elements have several roles in living organism. Some are essential components of enzymes where they attract substrate molecules and facilitate their conversion to specific end product (Nielson, 2002). In excessive concentrations, however, trace elements can negatively affect growth, reproduction and other biological functions. A safe and portable drinking water should conform to certain standards set by World Health Organisation (WHO) (Patience, 2014).

Heavy metals have become of particular interest in recent decades with the framework of environmental investigation. This has without doubt been due to the fact that highly sensitive analytical procedures are available for determining and detecting metal content with high precision (Salem et al., 2000).

Due to significant important of water to the living organism i.e. both plants and animals a lot of studies had been carried out to ascertain the quality of drinking water in different places all over the world, mainly by the determination of heavy metals present due to their impact on human health. 
BAJOPAS Volume 13 Number 1, June, 2020

Sa'id and Jimoh (2012), carried out study of different water samples taken from some selected areas of Kano metropolis and environs and heavy metals concentrations were measured. Ten water samples (4 wells, 4 boreholes and 2 dams) were analysed using atomic absorption spectrophotometer for their zinc, copper, cadmium and lead content and their levels compared to WHO specified maximum contaminant level.

Drinking water quality standards describes the quality parameters set for drinking water. Despite the truism that every human on this planet needs drinking water to survive and that water may contain many harmful constituents, there are no universally recognized and accepted international standards for drinking water (Deborah, 1999). Even where standards do exist and are applied the permitted concentrations of individual constituents may vary by as much as ten times from one set of standard to another. The aim of this Study is to determine the concentration of heavy metals in drinking water samples from selected Locations of Kauru Local government area, Kaduna state using Atomic Absorption Spectrophotometer.

\section{MATERIALS AND METHODS SAMPLE COLLECTION}

Five water samples were randomly collected from the various sampling sites 2 wells, 1 boreholes, 2 river/stream, and were Kauru well, Galadimawa well, Kauru borehole, Likarbu river, river Kayikara labelled A, B, C,D, and E. The water samples were collected in clean five (5) litre polythene plastics containers, the sample containers were rinsed with respective water samples before filling each with the sample.

\section{SAMPLE TREATMENT}

The samples were first allowed to settle followed by decantation. Five litres of each sample were measured and transferred to the new pot for evaporation on sand bath/stove, when the sample are reduced to about a litre is then transferred to a Pyrex beaker for the completion of the evaporation to dryness (Jimoh and Umar, 2015; Jimoh and Sholadoye, 2011).

Each of the evaporated samples were dissolved in a beaker with $10 \mathrm{ml}$ of $0.5 \mathrm{M}$ nitric acid $\left(\mathrm{HNO}_{3}\right)$. The solution was then filtered in a $30 \mathrm{ml}$ sample bottle and made up to the mark with $0.5 \mathrm{M}$ $\mathrm{HNO}_{3}$ acid. The addition of nitric acid, stabilizes the samples, maintains oxidation state of the element, make $\mathrm{pH}$ less than 2 and prevent precipitation (Egereonu et al., 2012).

\section{SAMPLE ANALYSIS}

Presence and concentration of the 5 metals were analysed in the sample solution using an AA500 GC London instrument atomic absorption spectrophotometer (AAS).

Atomic absorption spectrophotometer is commonly used in many analytical laboratories for determination of trace elements in water samples and in acid digests of sediments or biological tissues (Bamishaiye et al., 2011).

\section{RESULTS AND DISCUSSION}

The use of water for any purpose is guided by standards set by the World Health Organization (WHO) and other related agencies.

The trace metals analysed were considerably below the limit permitted by WHO's drinking water standard as presented in Figure 1 to 4(WHO 2011).

Nickel was detected in all the samples. The highest concentration of $4.90 \mu \mathrm{g} / \mathrm{L}$ was detected in sample $E$ which is river water as shown in fig.1. The Ni concentrations obtained were found to be below the WHO maximum permissible limit of $6 \mu \mathrm{g} / \mathrm{L}$ (WHO 2011).

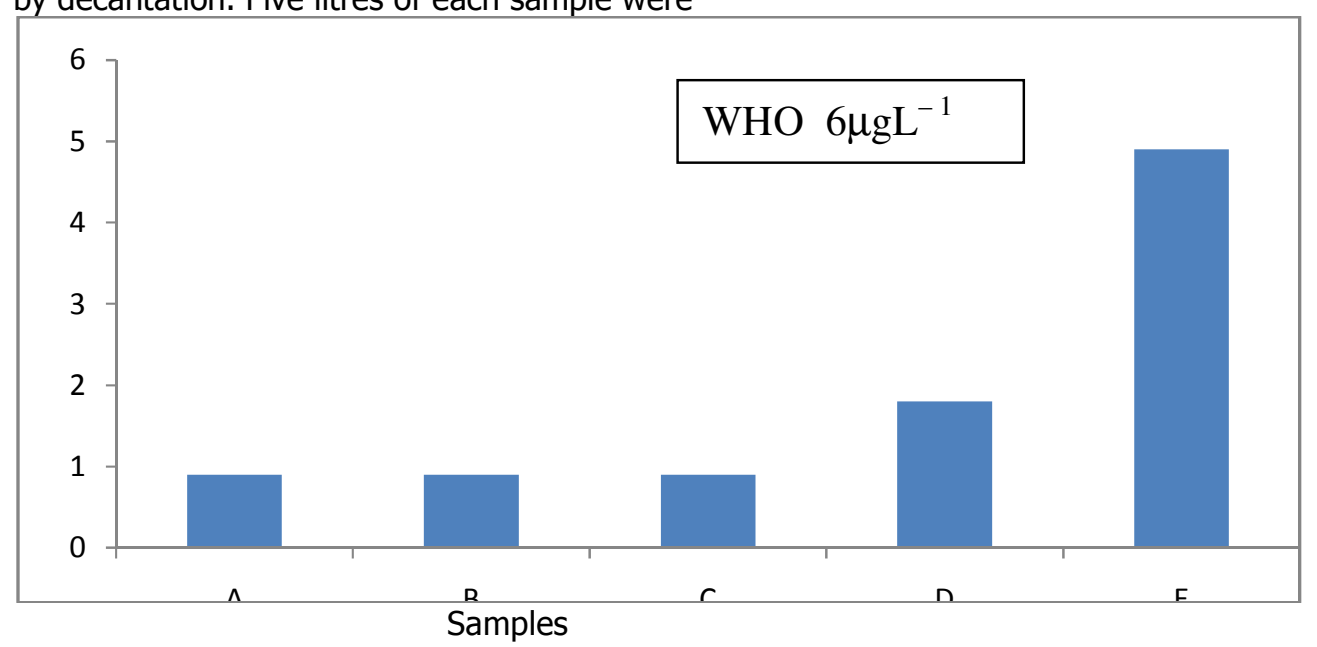

Fig 1:Concentrations of Nickel in $\mu \mathrm{g} / \mathrm{L}$ in the various water samples 
BAJOPAS Volume 13 Number 1, June, 2020

Ground water is sometimes affected by dissolved minerals from geological formation which may impact negatively on the water quality and this affect human health (Jimoh and Sholadaye, 2011).
Chromium was detected in sample $E$. While in samples $A, B$, Cand $D$ was not detected. The detected sample has the highest concentrations of $36.00 \mu \mathrm{g} / \mathrm{L}$ as shown in Fig.2

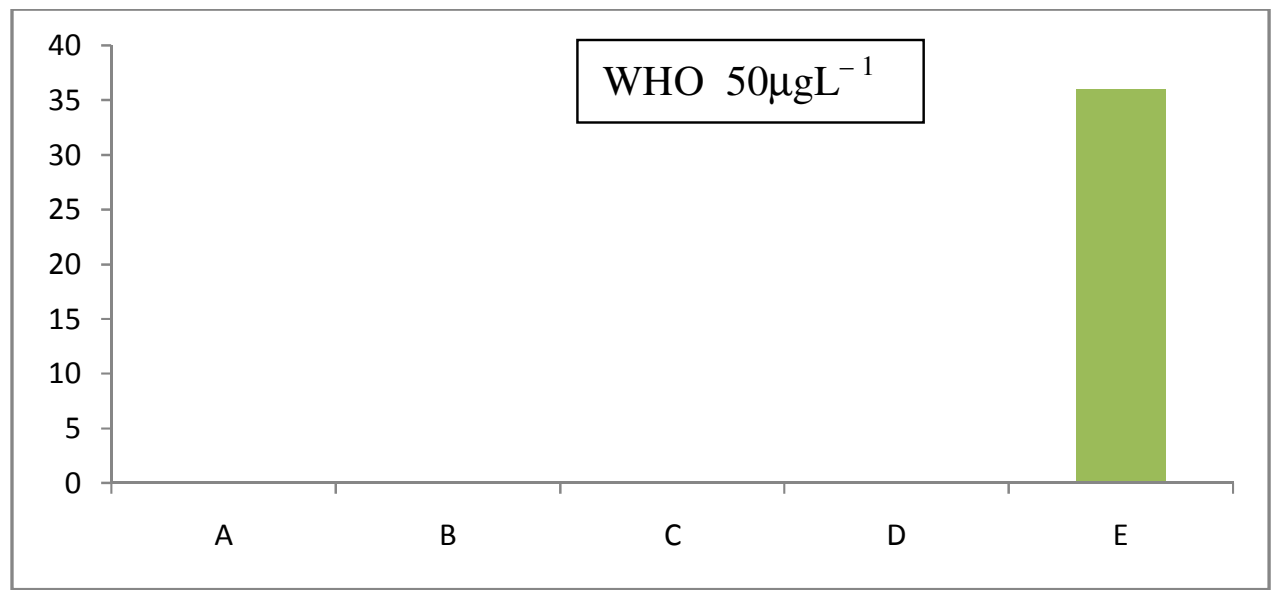

Fig.2: Concentrations of chromium in $\mu \mathrm{g} / \mathrm{L}$ in the various water samples

The chromium concentration was detected in samples $\mathrm{E}$ which represent river water. It was detected below the WHO maximum permissible limits of $50 \mu \mathrm{g} / \mathrm{L}$.

The concentration of cobalt in the water samples ranges from not detected to $4.76 \mu \mathrm{g} / \mathrm{L}$ as shown in fig.3

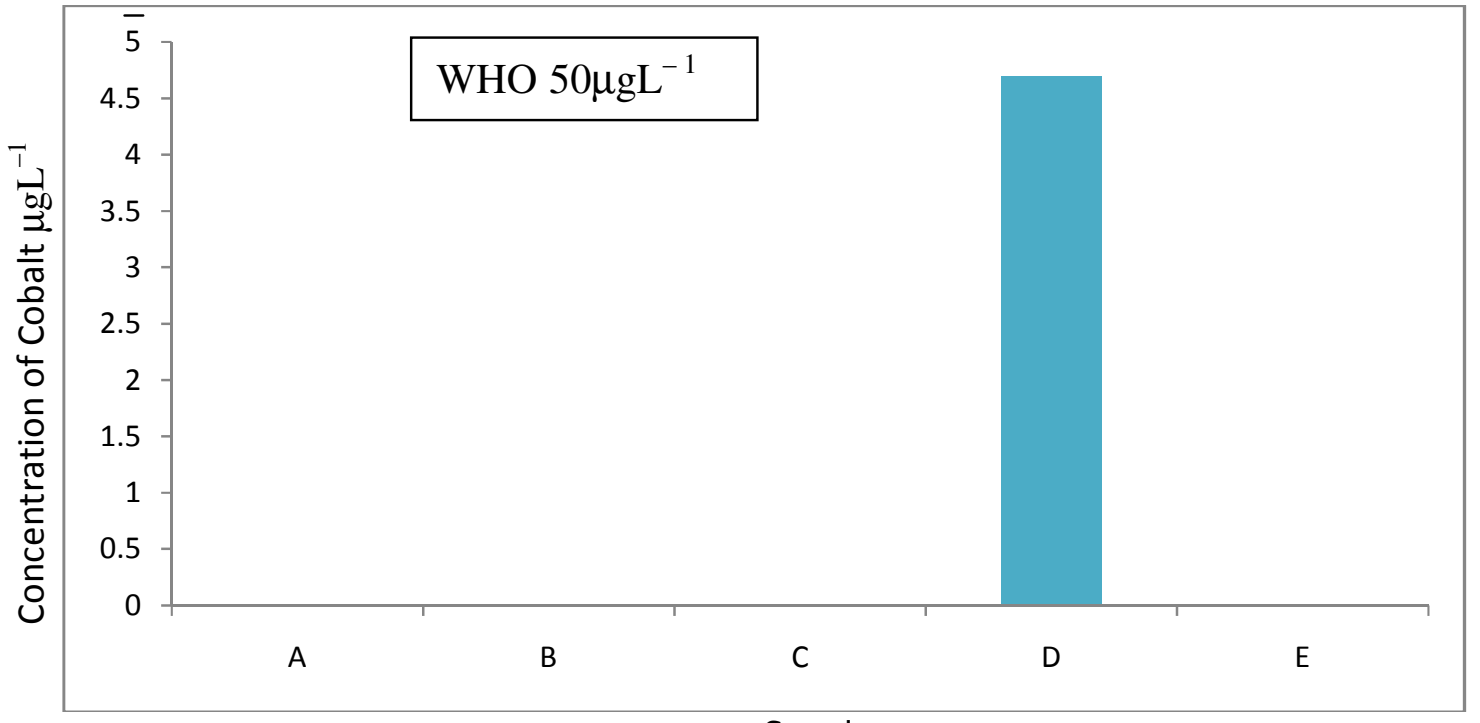

Samples

Fig.3: Concentration of cobalt in $\mu \mathrm{g} / \mathrm{L}$ in the various water samples.

Cobalt was detected only in sample $D$ corresponding to river water. It was not detected in samples $A$, $\mathrm{B}, \mathrm{C}$, and $\mathrm{E}$. The detected samples was below WHO permissible limits for cobalt in drinking water of $50 \mu \mathrm{g} / \mathrm{L}$ (WHO 2011).

Iron was detected in all the water samples but the highest concentrations of $230.3 \mu \mathrm{g} / \mathrm{L}$ was detected in sample B and the lowest concentration of $47.7 \mu \mathrm{g} / \mathrm{L}$ detected in sample $A$ as shown in Fig.4 


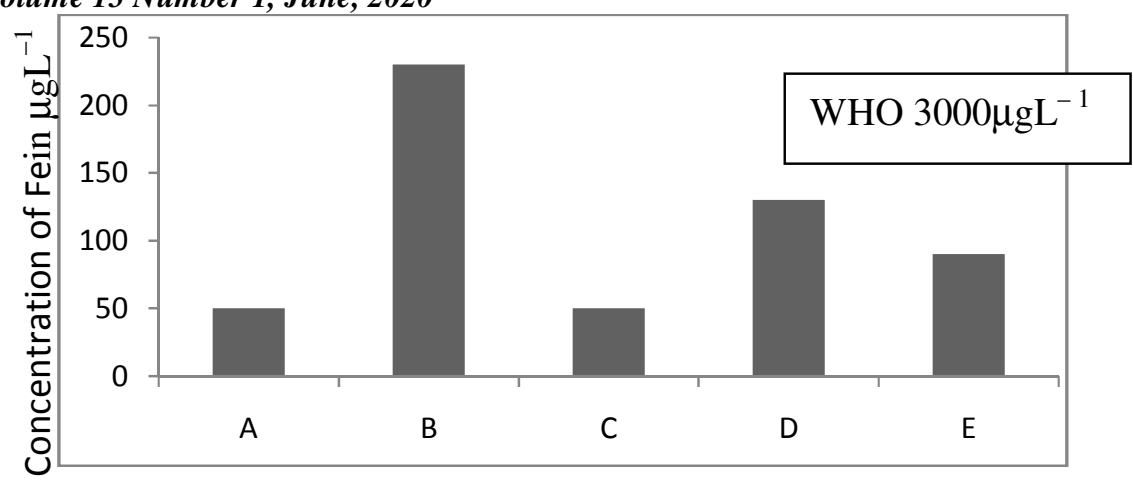

Samples

Fig.4: Concentrations of Iron in $\mu \mathrm{g} / \mathrm{L}$ in samples analysed.

The lowest concentration of iron was detected in one river water while the highest concentration of iron was detected in another River water. All samples analysed were below WHO permissible limits for iron in drinking water of $3000 \mu \mathrm{g} / \mathrm{L}(\mathrm{WHO}$ 2011). Cadmium was not detected in all the samples analysed.

From the discussion above, the excess heavy metal load of river and well water may be attributed to the discharge of domestic wastes, sewage, agricultural run-off and the rock type in this area (Indu et al., 2010).

\section{CONCLUSION}

The result of the analysis of the various water samples showed that the levels of trace elements,

\section{REFERENCES}

Adefemi, S.O. and Awokunmi, E. (2007). Assessment of the physic-chemical status of water samples from major dams in Ekiti State, Nigeria. Pak. Nut. 6(6) $657-659$.

Bamishaiye, E.I., Ogbenna, O. Jimoh, W.L. and Awagu, E.F. (2011). Determination of some trace elements in water samples within Kano metropolis. Chemistry Department, Bayero University, Kano, Nigeria.

Eugereonu, U.U., Anuo, A.U, and Egereonu, J.C.(2012).Comparative analysis of the degree of pollution of Ekitankwo River along Border communities;Mbaitoli,Ikeduru,Emeku and Uretta of Imo State - Nigeria.Analytical Journal of Science Vol.1 No 1 pp 8-9

Jimoh, W.O. andSholadaye, Q.O (2011). Trace elements as indicators of quality of drinking water in Offa Metropolis, Kwara state, Nigeria. Bayero Journal of Pure and Applied Sciences 4(2) 103 108.

Jimoh, W.O. and Umar, M.I. (2015). Determination of trace metal concentration in drinking water samples from SaniMainagge Quarter, Gwale local government area, Kano state, Nigeria.International Journal of Science Research in Environmental Sciences.3(9) pp.0341-0349, 2015. http://www.205pub.com/IJSRes

Patience,M.N.(2014). Assessment of some metals in water samples of Bayero University Kano and selected hospitals in Kano Metropolis. M.Sc.
$\mathrm{Fe}, \mathrm{Ni}, \mathrm{Cr}$, Co, and $\mathrm{Cd}$ were below WHO threshold limits while that of cadmium was not detected in any of the sample analyzed. This shows that all the water samples are safe and acceptable for drinking in the respective locations, also the work showed that iron and Chromium has the highest concentrations.

This research was conducted for some of the metals, cadmium, nickel, chromium, and iron in various drinking water samples. Further research work can be carried out for other metals, comparative analysis of the concentrations of elements in rainy and dry seasons, and determination of other parameters that was not investigated in this work.

Dissertation Department of Pure and Industrial Chemistry Bayero University, Kano.

Sa'id, M.D. andJimoh, W.L.O. (2012) Trace metals concentration in drinking water supplies from some selected areas of Kano metropolis and it's environs, Kano state, Nigeria. Biological and Environmental Science Journal for the Tropics, 9(3):212-214.

Sa'id, M.D. (2008). "Chemical analysis of some water samples across Kano state. Ph.D Thesis, Departme1nt of Pure and Industrial Chemistry Bayero University, Kano. pp.1-4.

Deborah S.F. (1999). "Water quality in internal river basins. Political Geography (Elservier) 18(4): 437 -476 ,

Nielson, F.H. (2002). Trace mineral deficiencies, Handbook of nutrition and food, edited by Carolyn D. Berdaniex, CRC Press. P4

Salem, H.M., Eweida, A. andFarag, A. (2000). Cairo University, Egypt, September, 2000 page 542 556 ICENielson, F.H. (2002). Trace mineral deficiencies, in handbook of nutrition and food, edited by Carolyn D. Berdaniex, CRC Press.

Indu, V.N, Kailash,S. Arumuugam,M. Grangadhar, K and Carlson,D.(2010). Trace metal quality of meenachil River at Kottayam, Kerara(India) by principal component Analysis work. Applied Science Journal 9(10): p1107.

WHO (2011).World Health Organization Guidelines for Drinking Water Quality, $4^{\text {th }}$ Edition Geneva, Switzerland. 